\title{
NONSPECIFIC DYSPLASIA OF THE CONNECTIVE TISSUE - A FACTOR OF VENOUS THROMBOEMBOLIC COMPLICATIONS IN ENDOPROSTHETICS OF HIP JOINTS
}

\author{
I.K. Venher, *N.I. Herasymiuk, S.Ya. Kostiv, I.I. Loyko, D.V. Khvalyboha \\ I. HORBACHEVSKY TERNOPIL NATIONAL MEDICAL UNIVERSITY, TERNOPIL, UKRAINE
}

Background. Important part of orthopedic surgery is endoprosthetics of hip joints, which eliminates pain syndrome, restores the amplitude of movement and the support ability of lower limbs. But some complications usually take place; venous thromboembolism is leading among them.

Objective. The aim of the study was to investigate endothelial dysfunction and activity of the hemocoagulation system at different levels of VTEC risks and thus to work out the strategy of thromboprophylaxis in patients with osteoarthrosis of the hip joint and femoral neck fracture combined with non-specific dysplasia of the connective tissue.

Methods. 219 patients of a mean age of 64.7 \pm 3.8 years old underwent surgery. In 137 (62.1\%) cases, a total cement hip replacement was performed for osteoarthritis. 82 (37.4\%) patients underwent total and unipolar cement hip replacement for cervical femoral neck fractures.

Results. Clinical manifestations of non-specific connective tissue dysplasia were detected in 83 (37.9\%) patients that was confirmed by the laboratory determination of the level of general, bound and free oxyproline. In the postoperative period, the thrombotic process in the venous system of the inferior vena cava was diagnosed in 23 (10.5\%) cases. The level of indicators of endothelium status dysfunction was much more significant in the patients in cases of nonspecific dysplasia of connective tissue. Operative intervention on the hip joint in the patients with nonspecific dysplasia of connective tissue in 11 (13.3\%) cases was complicated by development of venous thrombosis. In the patients without non-specific connective tissue dysplasia, postoperative thrombosis in the system of the inferior vena cava was diagnosed in 12 (8.8\%) cases.

Conclusions. Patients with osteoarthrosis of the hip joint and the femoral neck fracture accompanied by the non-specific dysplasia of the connective tissue are characterized by high levels of endothelial dysfunction and increased activity of the blood-coagulation system.

KEYWORDS: endoprosthetics; thromboembolism; endothelial dysfunction; dysplasia.

\begin{tabular}{ll}
\multicolumn{2}{c}{ Abbreviations } \\
AT III & antithrombin III \\
CTD & non-specific connective tissue dysplasia \\
DVT & deep vein thrombosis \\
FBA & fibrinolytic blood activity \\
FDP & fibrin degradation product \\
FPA & fibrinopeptide A \\
IVC & inferior vena cava \\
LMWH low molecular weight heparins \\
NCTD & non-specific connective tissue \\
& dysplasia \\
PRT & plasma recalcification time \\
SCFM & soluble complexes of fibrin-monomers \\
TFA & total fibrinolytic activity \\
TPA & thromboembolism of the pulmonary artery \\
VEGF & vascular endothelial growth factor \\
IVC & inferior vena cava \\
VTEC & venous thromboembolic complications
\end{tabular}

Introduction

Significant occurrence of diseases of the lower extremities joints leads to the search for

*Corresponding author: Nazar I. Herasymiuk, M.D., PhD, Associate Professor of the Department of Surgery No 2, I. Horbachevsky Ternopil National Medical University, Ternopil, Ukraine.E-mail: herasymiuknazar@gmail.com. effective methods of treatment. Among them endoprosthetics of the joints is foremost. It allows eliminating pain syndrome, restoring the amplitude of movement and the support ability of the lower limb [1]. During endoprosthetics, a number of complications often occur; VTEC is leading among them [2]. Without VTE prophylaxis, the overall VTE incidence in medical and general surgery of the hospitalized patients is in the range of $10-40 \%$, while it ranges up to $40-60 \%$ in major orthopaedic surgery. With routine VTE prophylaxis, fatal pulmonary embolism is uncommon in orthopaedic patients and the rates of symptomatic VTE within three months are in the range of $1.3-10 \%$ [3]. VTE preventive treatment methods are divided into mechanical and pharmacological. The mechanical include mobilization, graduated compression stockings, intermittent pneumatic compression device and venous foot pumps; the pharmacological include aspirin, unfractionated heparin, low molecular weight heparin (LMWH), adjusted dose vitamin $\mathrm{K}$ antagonists, synthetic 
pentasaccharide factor Xa inhibitor and newer oral anticoagulants. LMWH seems to be more efficient overall compared with the other available agents. We are still sceptical about the use of aspirin as a sole method of prophylaxis in total hip and knee replacement and hip fracture surgery, while controversy still exists regarding the use of VTE prophylaxis in knee arthroscopy, lower leg injuries and upper extremity surgery [3]. The factors that predispose a high risk of venous thromboembolism in the patients undergoing endoprosthetics of the joints are taken into account [4]. But there is no significant decrease of frequency of VTEC development [5].

The aim of the study was to investigate endothelial dysfunction and activity of the hemocoagulation system at different levels of VTEC risks and thus to work out the strategy of thromboprophylaxis in patients with osteoarthrosis of the hip joint and femoral neck fracture combined with non-specific dysplasia of the connective tissue.

\section{Methods}

219 patients of a mean age of $64.7 \pm 3.8$ years old underwent surgery. In 137 (62.1\%) cases, total cement hip replacement for osteoarthritis was performed. 82 (37.4\%) patients underwent total and unipolar cement hip replacement for cervical femoral neck fractures. Operative intervention was carried out under subdural anaesthesia with bupivacaine.

Clinical manifestations of non-specific connective tissue dysplasia (NCTD) were detected in $83(37.9 \%)$ patients. This was confirmed by laboratory determination of the level of general, bound and free oxyproline. The method of P.N. Sharaev for a calibrated curve was used.

Mechanical prophylaxis of VTEC by elastic compression of the lower extremities was used in all cases. Pharmacological prevention of VTEC was performed using LMWH (enoxaparin).

The study included 136 patients (group I) with hip joint osteoarthrosis and femoral neck fracture and 83 patients (group II) with osteoarthrosis of the hip joint and femoral neck fracture and associated NCTD.

In the postoperative period, the thrombotic process in the venous system of the inferior vena cava (IVC) was diagnosed in 23 (10.5\%) cases. Operative intervention on the hip joint in the patients with NCTD in $11(13.3 \%)$ cases was complicated by the development of venous thrombosis. In the patients without NCTD, postoperative thrombosis in the venous system of
IVC was diagnosed in 12 (8.8\%) cases. In 21 patients, postoperative thrombosis was detected in the deep venous system of IVC and only in two cases in the superficial venous system.

Monitoring of the thrombotic process in the venous system of the inferior vena cava was performed by duplex ultrasound scans of the vessels of the lower extremities by Sonoscape S8Exp with a frequency of $5-12 \mathrm{MHz}$ and 2.5-4 MHz from the first day of the postoperative period. In the first day of the postoperative period, in two patients the thrombotic processes in the deep veins of the IVC system was diagnosed, on the $2^{\text {nd }}$ day - in 5 cases, on the $3^{\text {rd }}$ day - in one patient, on the $6^{\text {th }}, 7^{\text {th }}$ and $8^{\text {th }}$ days in 3,5 and 2 cases, respectively, and on the $11^{\text {th }}$ and $12^{\text {th }}$ day - in one and two patients, respectively. In the superficial venous system of the lower limb, the thrombotic process was detected in two cases on the $6^{\text {th }}$ and $10^{\text {th }}$ day of the postoperative period.

$8(34.9 \%)$ cases of the venous thrombotic processes were diagnosed within the first three days of the early postoperative period in the patients with NCTD.

To choose the treatment tactics for venous thrombosis of the IVC system, the determination of thrombogenicity of thrombotic masses was performed. The elastographic properties of the venous thrombus were studied by the ultrasonic system Siemens Acuson S2000 (Germany). At the shear wave expansion speed of $2.5-2.6 \mathrm{~m} / \mathrm{s}$ there is a high risk of embologenity of the thrombi, at the shear wave expansion speed of 2.7-2.9 $\mathrm{m} / \mathrm{s}$ there is a moderate risk of embologenity of the thrombi, at the shear wave expansion speed of $3.0 \mathrm{~m} / \mathrm{s}$ and more there is no threat of embolism.

In two cases on the second day of the postoperative period the propagation of the shear wave at $2.5-2.6 \mathrm{~m} / \mathrm{s}$ in the thrombotic mass of the vein was established using the ultrasonic system Siemens Acuson S2000 (Germany), which is a significant threat to the development of pulmonary embolism. This was an indication for urgent surgical intervention to eliminate the threat of TPA. In all other cases anticoagulant therapy was performed.

The rate of coagulation and fibrinolytic system functioning was determined: fibrinogen was determined by gravimetric method according to R.A. Rutberg; activity of the fibrin stabilizing factor (F XIII) - by means of the "set for determination of FBA-XIII" of the scientific and production firm SIMKO Ltd (Lviv); thromboplastic activity of blood - by B.A. Kudryashov and 
P.D. Ulytina method; Plasma recalcification time - by Bergerhof and Rock method; plasmin, plasminogen, total fibrinolytic activity (TFA) - by V.A. Monastyrska et al. method (1988); time of lysis of euglobin clots - using the "Set for the determination of fibrinolytic blood plasma activity" by the scientific and production firm SIMKO Ltd (Lviv). D-dimer was determined by immunoanalytical method using a coagulometer. The soluble fibrin-monomer complexes were determined using the Tablet method.

The state of the endothelial system was evaluated by determining the level of endothelial dysfunction markers: the concentration of $\mathrm{P}$-selectin, E-selectin, tissue plasminogen activator (t-PA), type 1 vascular endothelium adhesion molecule (sVCA M-1) was determined using the Bender MedSystems (Austria) for immune-enzyme analysis. Endothelin-1 concentration was determined using the Biomedica (Canada) kits for immune-enzyme analysis. The reaction was evaluated on a SUNRISE microplate semimetric photometer (Tecan, Austria) using the Hydroflex washing station (Tecan, Austria). To determine circulating endothelial cells (CEC) the J. Hiadovec and N.N. Pertishchev et al. method (2001) was used. The level of nitrogen oxide (NO) metabolites, vascular endothelial growth factor (VEGF) was determined by the immune enzyme method using the KHGO111VTGF analyser and the Griess reagent.

\section{Results}

The state of the endothelial system reflects the pathology of the organism. In the patients with osteoarthrosis of the hip joint and femoral neck fracture an increased level of all endothelial system markers was noted. At the same time, the level of indicators of endothelium status was more significant in the patients (group II) with pathology of hip joint in the presence of NCDT (Table 1). Thus, at the preoperative stage of treatment, the blood level of circulating endothelial cells was higher in 1.8 times $(p<0.001)$, endothelin-1 level was increased in 2.2 times $(p<0.001), P$-selectin and E-selectin levels increased in 1.5 times $(p<0.001)$ and 1.2 times $(p<0.05)$ respectively, compare to indicators of healthy persons. There was a 1.8 fold $(p<0.001)$ increase of blood NO levels and a slight 1.2 fold $(p<0.05)$ increase of the VEGF blood contents.

Operative intervention in the patients of group II contributed to development of severe endothelial dysfunction. This was especially noticeable at the twelfth hour of the postoperative period. The latter occurred due to a
1.5 fold increase $(p<0.05)$ in the contents of circulating endothelial cells in blood and a 1.5 fold increase $(p<0.05)$ in endothelin-1, a 1.2 fold decrease $(p<0.05)$ and a 1.5 fold decrease $(p<0.05)$ of $P$-selective and E-selectin levels respectively, to compare with the preoperative period. There was also a slight increase of NO contents in blood and a 1.3 fold $(p<0.05)$ increase of VEGF contents in blood.

At the stage of preoperative preparation of patients, activation of the hemostasis system was observed (Table 2). This was more significant among the patients of the group II. The indicators that characterize the condition of the coagulation system of patients with NCTD were in 1.2 times higher than those of the patients without NCTD. In the patients with NCTD in the preoperative period the content of fibrinogen was $5.07 \pm 0.35 \mathrm{~g} / \mathrm{l}$, (in healthy patients $3.52+0.34 \mathrm{~g} / \mathrm{l}(\mathrm{p}<0.05)$. At the same time, an increase of the contents of SCFM in blood was determined as of $0.57 \pm 0.11$ extr. units $(p<0.05)$. Monomers that were formed as a result of separation of fibrinopeptides $A$ and $B$ from fibrinogen under the influence of thrombin, form macromolecular degradation products of fibrin with it. Trombinemia was confirmed by the increase up to $2.61 \pm 0.23 \mathrm{ng} / \mathrm{l}(\mathrm{p}<0.05)$ of FPA content. At the same time, an increased up to $6.92 \pm 2.09 \mu \mathrm{g} / \mathrm{l}($ norm $4.71 \pm 1.58 \mu \mathrm{g} / \mathrm{ml})$ content of the FDP was detected. It took place on the background of minimal changes of the FBA and in the absence of any changes in the level of AT III and PRT.

Significant changes of coagulation system occurred during the intraoperative period of surgical treatment of the patient. At the traumatic stage of surgical intervention, a hypercoagulative condition of blood developed. During that period, the fibrinogen level in the blood exceeded the preoperative level by only $10.2 \%$, then the blood contents of SCFM was increased in 1.4 times $(p<0.05)$, the contents of FPA was increased in 1.7 times $(p<0.001)$, the contents of FDP was increased in 1.9 times $(p<0.001)$. It took place on the background of reduced fibrinolytic activity of blood, reduced contents of AT III in blood, decrease of PRT (Table 3).

The maximum level of hypercoagulation reached at $6 \mathrm{~h}$. of early postoperative period. At that time, the blood fibrinogen level exceeded the preoperative rate in 1.3 times $(p<0.05)$, and the contents of SCFM in blood was increased in $2.1(p<0.001)$ times, the content of FPA and FDP - in 2.7 and $2.8(p<0.001)$ times, respectively. It took place at a 1.3 fold decrease 

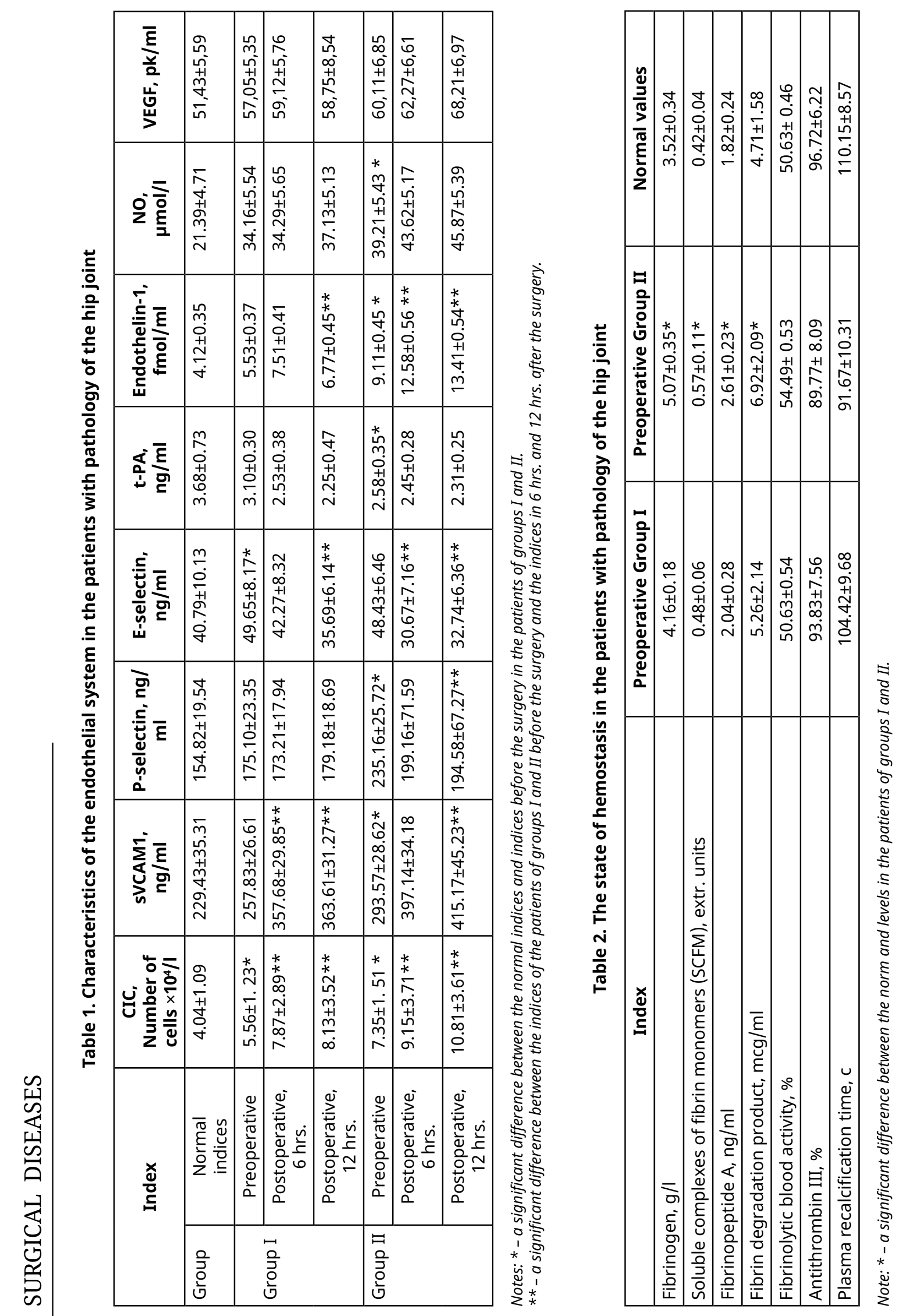
Table 3. The intraoperative state of hemostasis in the patients with hip arthritis and NCTD

\begin{tabular}{|l|c|c|c|c|c|}
\hline \multicolumn{1}{|c|}{ Index } & Preoperative & $\begin{array}{c}\text { Traumatic } \\
\text { stage }\end{array}$ & 3hr. p/o & 6hr. p/o & 12 hr. p/o \\
\hline Fibrinogen, g/l & $5.07 \pm 0.35$ & $5.59 \pm 0.46$ & $5.82 \pm 0.49$ & $6.54 \pm 0.48 *$ & $6.43 \pm 0.47 *$ \\
\hline SCFM, units.extr. & $0.57 \pm 0.11$ & $0.81 \pm 0.11^{*}$ & $1.23 \pm 0.19 * *$ & $1.24 \pm 0.18^{*} *$ & $0.97 \pm 0.21 * *$ \\
\hline FPA, ng/ml & $2.61 \pm 0.23$ & $4.51 \pm 0.36^{*}$ & $7.05 \pm 0.35^{*}$ & $6.94 \pm 0.43^{*}$ & $6.39 \pm 0.48 *$ \\
\hline FDP, $\mathrm{mcg} / \mathrm{ml}$ & $6.92 \pm 2.09$ & $13.47 \pm 3.56 *$ & $18.25 \pm 4.41 *$ & $19.12 \pm 4.38^{*}$ & $14.89 \pm 4.78^{*}$ \\
\hline FBA, \% & $54.49 \pm 3.53$ & $43.75 \pm 4.13$ & $42.19 \pm 4.16^{*}$ & $43.41 \pm 4.23^{*}$ & $45.72 \pm 4.27 *$ \\
\hline AT III, \% & $89.77+6.09$ & $84.12+6.55$ & $81.24+5.49$ & $84.54+5.75$ & $85.56+5.68$ \\
\hline PRT, sec & $91.67 \pm 7.31$ & $80.57 \pm 7.33$ & $82.65 \pm 7.72$ & $84.59 \pm 7.37$ & $89.28 \pm 8.19$ \\
\hline
\end{tabular}

Notes: * $-p<0.05$ in comparison with preoperative indices;

** $-p<0.001$ in comparison with preoperative indices.

$(p<0.05)$ of fibrinolytic activity of blood, a decrease of the contents of AT III, and a slight decrease of PRT.

Operative intervention significantly influenced the aggregation state of patients' blood. So, at the traumatic stage of surgical intervention and up to 6 hours of the early postoperative period, the platelet aggregation rate significantly increased with a slight decrease in platelet aggregation time. In the same period, there was a decrease in the activity of the fibrinolytic blood system. This level of anticoagulant system with a tendency to exacerbation was maintained until the $3^{\text {rd }} \mathrm{h}$. of early postoperative period. From the $6^{\text {th }}$ hour of early postoperative period a gradual increase in the activity of the fibrinolytic blood system was evidenced.

The results of the study of hemostasis in the patients with NCTD at the intraoperative stage of surgical intervention at the increase of hypercoagulative properties of blood, strengthening its aggregation ability with a depressed state of the fibrinolytic blood system indicated development of conditions for thrombotic process formation in the venous system. It could be promoted by a high level of endothelial dysfunction, which increased in the conditions of surgical intervention.

\section{Discussion}

A number of complications often occurs in cases of endoproathetics. VTEC among them is still urgent [1]. Patients with surgical interventions on the large joints of the lower extremities require anticoagulant prophylaxis [2]. Both the classical factors of the Virchow's triad, and the specific factors, which are specific for the endoprosthetics of the hip joint [5], as well as individual factors of the patients risk and pathology of large joints are taken into account [5]. However, in thromboprophylaxis the incidence of thrombosis of deep veins after the hip replacement is $0.8-9.0 \%$, pulmonary embolism - from 1.4 to $6.0 \%$ [6]. The latter gives the right to suppose that during the thromboprophylaxis the factors with different etiopathogenetic origin are not taken into account, but there is a direct or indirect activation of procoagulant FBAs in their presence. Thus, much attention should be paid to nonspecific dysplasia of the connective tissue [7].

The patients with hip osteoarthrosis, femoral neck fracture with NCTD are characterized by increased degree of endothelial dysfunction, a greater activity of the haemocoagulation system compared to the patients without NCTD. Thus, in the preoperative stage, the blood level of markers of endothelial dysfunction in the patients with NCTD is in 1.5-2.2 times $(P<0.001)$ higher compare to the patients without NCTD. It causes a 1.2 fold higher activity of the blood hemocoagulation system of these patients.

The patients with pathology of the hip joint with NCTD experience an increased degree of endothelial dysfunction at the intraoperative stage which leads to hypercoagulation. These changes of the endothelial system and the hemocoagulation system create favourable conditions for VTEC.

Endoprosthetics of the hip joint is a highrisk group of VTEC and requires anticoagulation prophylaxis. A number of present recommendations offer pharmacological prophylaxis for prevention of VTEC in cases of endoprosthetics of large joints. The use of low molecular heparins, synthetic inhibitors of Xa and IIa factors of blood coagulation or antagonists of vitamin $\mathrm{K}$ is recommended for this [8]. However, the rate of VTEC development in the postoperative period is trill at the previous level.

In order to reduce the postoperative DVT, attention should be paid to intraoperative changes in the haemocoagulation state of the operated patients. [9] There are reports [10] 
about the diagnosis of the thrombotic process in the IVC system after the end of the surgical intervention.

During the surgical intervention for the pathology of the hip joint from the second half of the traumatic phase and during the first 2-3 hours of the early postoperative period, an increase of the level of hypercoagulation due to fibrin-monomeric complexes is observed. It is the unfractionated heparin that has a predominant influence on the IIa factor (thrombin fibrinogen) of the hemocoagulation cascade. And thromboprophylaxis should be started straight after the end of the surgical intervention with the prescription of non-fractional heparin and should be continued until the first injection of LMWH, which has a predominant influence on the Xa factor of the blood coagulation system [11].

The use of oral form of unfractionated heparin is promising [12]. This has become possible due to the combination of unfractionated heparin and the molecule N [8 (2-hydroxybenzene) amine] carrier - sodium caprylate. The third phase of coagulation cascade study showed that oral heparin reduces the incidence of postoperative thrombotic formation.

\section{Conclusions}

The patients with osteoarthrosis of the hip joint and femoral neck fracture and non-specific dysplasia of the connective tissue are characterized by expressed levels of endothelial dys- function and increased activity of the hemocoagulation system.

In the postoperative period after endoprosthetics of hip joints, in the patients with osteoarthrosis of the hip joint and femoral neck fracture and non-specific dysplasia of the connective tissue, VTEC was diagnosed in $13.3 \%$ of cases, in the patients with osteoarthrosis of the hip joint and femoral neck fracture in the absence of nonspecific dysplasia of the connective tissue VTEC was revealed in $8.8 \%$ of cases.

The thromboprophylaxis of VTEC in the patients with endoprosthetics of hip joints should be started straight after the start of surgical intervention with the prescription of non-fractional heparin, which has a predominant effect on the IIa FBA of the hemocoagulation cascade and should be continued until the first injection of $\mathrm{LMWH}$, which has a dominant influence on $\mathrm{Ha}$ factor of the hemocoagulation system.

\section{Funding}

This research received no external funding.

\section{Conflict of Interests}

The authors declare no conflict of interest.

\section{Author Contributions}

Venher I.K. - conceptualization, project administration, supervision; Herasymiuk N.I. resources, investigation, writing - original draft, writing - review \& editing; Kostiv S.Ya. - methodology, formal analysis; Loyko I.I. - validation, writing - original draft; Khvalyboha D.V. - investigation.

\title{
НЕСПЕЦИФІЧНА ДИСПЛАЗІЯ СПОЛУЧНОЇ ТКАНИНИ - ФАКТОР РИЗИКУ ВЕНОЗНИХ ТРОМБОЕМБОЛІЙ ПРИ ЕНДОПРОТЕЗУВАННІ КУЛЬШОВОГО СУГЛОБА
}

\author{
I.K. Венгер, Н.I. Герасимюк, С.Я. Костів, I.I. Лойко, А.В. Хвалибога \\ ТЕРНОПІЛЬСЬКИЙ НАЦІОНАЛЬНИЙ МЕДИЧНИЙ УНІВЕРСИТЕТ IМЕНІ І.Я. ГОРБАЧЕВСЬКОГО, \\ ТЕРНОПІЛЬ, УКРАЇНА
}

Вступ. Важливою складовою ортопедичної хірургії є ендопротезування тазостегнових суглобів, що усуває больовий синдром, відновлює амплітуду рухів та підтримуючу здатність нижньої кінцівки. Але чі втручання супроводжуються рядом ускладнень, серед яких провідне місце займає венозна тромбоемболія.

Мета. Дослідити ендотеліальну дисфункцію та активність системи гемокоагуляції на різних рівнях ризиків венозного тромбемболізму та, таким чином, розробити стратегію тромбопрофілактики у пацієнтів з остеоартрозом з переломом шийки тазостегнового суглоба та стегнової кістки у поєднанні з неспецифічною дисплазією сполучної тканини.

Методи. Оперовано 219 пацієнтів із середнім віком 64,7士3,8. У 137 (62,1\%) спостереженнях проведено тотальне цементне ендопротезування стегна з остеоартритом. 82 (37,4\%) пацієнтів отримали тотальну та однополярну заміну стегна при переломах шийки стегнової кістки. 
Результати. Клінічні прояви неспецифічної дисплазії сполучної тканини були виявлені у 83 (37,9\%) пацієнтів, що було підтверджено лабораторним визначенням рівня загального, зв'язаного та вільного оксипроліну. У післяопераційному періоді в 23 (10,5\%) спостереженнях діагностували тромботичний процес у венозній системі нижньої порожнистої вени. Рівень показників ендотеліальної дисфункції був суттєво вираженіший у пацієнтів за наявності неспецифічної дисплазії сполучної тканини. Оперативне втручання на тазостегновому суглобі у пацієнтів з неспецифічною дисплазією сполучної тканини у 11 (13,3\%) випадках ускладнилось розвитком венозного тромбозу. У пацієнтів без неспецифічної дисплазії сполучної тканини післяопераційний тромбоз у системі нижньої порожнистої вени був діагностований у 12 (8,8\%) спостереженнях.

Висновки. Пацієнти з остеоартрозом тазостегнового суглоба та переломом шийки стегнової кістки, що супроводжуються неспецифічною дисплазією сполучної тканини, характеризуються вираженим рівнем ендотеліальної дисфункції та підвищеною активністю системи згортання крові.

КЛЮЧОВІ СЛОВА: ендопротезування; тромбемболія; ендотеліальна дисфункція; дисплазія.

\section{Інформація про авторів}

Венгер I.K. - доктор медичних наук, професор, завідувач кафедри хірургії № 2, Тернопільський національний медичний університет імені І.Я. Горбачевського, Тернопіль, Україна.

Герасимюк H.I. - кандидат медичних наук, доцент кафедри хірургії № 2, Тернопільський національний медичний університет імені І.Я. Горбачевського, Тернопіль, Україна.

Костів С.Я. - доктор медичних наук, професор, професор кафедри хірургії № 2, Тернопільський національний медичний університет імені І.Я. Горбачевського, Тернопіль, Україна.

Лойко I.I. - кандидат медичних наук, доцент кафедри хірургії № 2, Тернопільський національний медичний університет імені І.Я. Горбачевського, Тернопіль, Україна.

Хвалибога Д.В. - аспірант кафедри хірургії № 2, Тернопільський національний медичний університет імені І.Я. Горбачевського, Тернопіль, Україна.

\section{Information about the authors}

Venher I.K. - MD, Ph.D., Professor, Department of Surgery No. 2, I. Horbachevsky Ternopil National Medical University, Ternopil, Ukraine.

ORCID https://orcid.org/0000-0003-0170-1995, e-mail: vengerik@tdmu.edu.ua

Herasymiuk N.I. - MD, Ph.D., Professor, Department of Surgery No. 2, I. Horbachevsky Ternopil National Medical University, Ternopil, Ukraine.

ORCID https://orcid.org/0000-0002-5476-268X, e-mail: herasymyuk_n@tdmu.edu.ua

Kostiv S.Ya. - MD, Ph.D., Professor, Department of Surgery No. 2, I. Horbachevsky Ternopil National Medical University, Ternopil, Ukraine.

ORCID https://orcid.org/0000-0002-2991-3263, e-mail: kostivsj@tdmu.edu.ua

Loyko I.I. - MD, Ph.D., Professor, Department of Surgery No. 2, I. Horbachevsky Ternopil National Medical University, Ternopil, Ukraine.

ORCID https://orcid.org/0000-0003-2967-1054, e-mail: loikoii@tdmu.edu.ua

Khvalyboha D.V. - MD, postgraduate student, Department of Surgery No. 2, I. Horbachevsky Ternopil National Medical University, Ternopil, Ukraine.

\section{References}

1. Lychagin AV, Cherepanov VG, Petrov PI, Vyazankin IA, Brkich GE. Pre-Surgery Planning of Lower Limbs Major Joints Arthroplasty. Open Access Macedonian Journal of Medical Sciences. 2019 Sep 15;7(17):2838-43.

doi: $10.3889 /$ oamjms.2019.690

2. Schünemann $H J$, Cushman $M$, Burnett $A E$, Kahn SR, Beyer-Westendorf J, Spencer FA, Rezende SM, Zakai NA, Bauer KA, Dentali F, Lansing J. American Society of Hematology 2018 guidelines for management of venous thromboembolism: pro- phylaxis for hospitalized and nonhospitalized medical patients. Blood advances. 2018 Nov 27;2(22):3198225.

doi: 10.1182/bloodadvances.2018022954

3. Flevas DA, Megaloikonomos PD, Dimopoulos L, Mitsiokapa E, Koulouvaris P, Mavrogenis AF. Thromboembolism prophylaxis in orthopaedics: an update. EFORT open reviews. 2018 Apr;3(4):136-48.

doi: 10.1302/2058-5241.3.170018

4. Yasunaga $H$, Tsuchiya K, Matsuyama Y, Ohe K. High-volume surgeons in regard to reductions in 
operating time, blood loss, and postoperative complications for total hip arthroplasty. Journal of Orthopaedic Science. 2009 Jan 1;14(1):3-9.

doi: $10.1007 / \mathrm{s} 00776-008-1289$

5. Feng W, Wu K, Liu Z, Kong G, Deng Z, Chen S, Wu Y, Chen M, Liu S, Wang H. Oral direct factor Xa inhibitor versus enoxaparin for thromboprophylaxis after hip or knee arthroplasty: systemic review, traditional meta-analysis, dose-response meta-analysis and network meta-analysis. Thrombosis research. 2015 Dec 1;136(6):1133-44.

doi: 10.1016/j.thromres.2015.10.009

6. Yan X, Gu X, Xu Z, Lin H, Wu B. Cost-effectiveness of different strategies for the prevention of venous thromboembolism after Total hip replacement in China. Advances in therapy. 2017 Feb 1;34(2):466-80. doi: 10.1007/s12325-016-0460-0

7. Venher I, Kostiv S, Nenashko I. Non-specific connective tissue dysplasia - a risk factor for postoperative thrombosis in the venous system of lower extremities. Health Problems of Civilization. 2016 Jan 1;10(2):51-4.

doi: $10.5114 /$ hpc.2016.59633

8. Re-Mobilize Writing Committee. Oral thrombin inhibitor dabigatran etexilate vs North American enoxaparin regimen for prevention of venous thromboembolism after knee arthroplasty surgery. The Journal of arthroplasty. 2009 Jan 1;24(1):1-9.

doi: 10.1016/j.arth.2008.01.132
9. Liew NC, Alemany GV, Angchaisuksiri $P$, Bang SM, Choi G, DE DS, Hong JM, Lee L, Li YJ, Rajamoney GN, Suviraj J. Asian venous thromboembolism guidelines: updated recommendations for the prevention of venous thromboembolism. International angiology: a journal of the International Union of Angiology. 2017 Feb;36(1):1-20.

doi: 10.23736/S0392-9590.16.03765-2

10. Van PY, Schreiber MA. Contemporary thromboprophylaxis of trauma patients. Current opinion in critical care. 2016 Dec 1;22(6):607-12.

doi: 10.1097/MCC.0000000000000365

11. Diamantouros A, Kiss A, Papastavros T, David U, Zwarenstein M, Geerts WH. The TOronto ThromboProphylaxis Patient Safety Initiative (TOPPS): A cluster randomised trial. Research in Social and Administrative Pharmacy. 2017 Sep 1;13(5):997-1003.

doi: 10.1016/j.sapharm.2017.05.015

12. Zhang J, Xu J, Zhang $W$, Jiang $M$, Liu J, Xu L, Liu G, Zhao Z. Quality Appraisal of Guidelines on Cancer-Associated Thrombosis Using AGREE II Instrument and Analysis of Current Status of New Oral Anticoagulants. Clinical and Applied Thrombosis/ Hemostasis. 2019 Apr 26;25:1076029619846562.

doi: $10.1177 / 1076029619846562$

Received 23 March 2020; revised 15 May 2020 accepted 11 June 2020.

This is open access article distributed under the Creative Commons Attribution License, which permits unrestricted use, distribution, and reproduction in any medium, provided the original work is properly cited. 